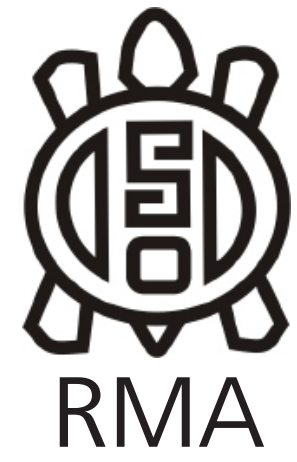

Arqueología

\title{
La popularización de la arqueología prehistórica en la Argentina: el problema de la antigüedad del hombre y sus dispositivos visuales (1860-1920)
}

The popularization of prehistoric archaeology in Argentina: the problem of the antiquity of man and its visual devices (1860-1920)

Cecilia Simón*

*Departamento de Humanidades, Universidad Nacional del Sur, Argentina. E-mail: ceciliasimon9156@gmail.com

\begin{abstract}
Resumen
En el presente artículo nos proponemos analizar la popularización de la arqueología prehistórica en la Argentina a comienzos del siglo XX, a partir del estudio de los dispositivos visuales creados y utilizados para presentar saberes en torno al origen y la evolución de nuestra especie. Para ello presentamos tres ejemplos sobre las formas que adquirieron esos conocimientos y las prácticas asociadas con su estudio: el derrotero visual de las hipótesis explicativas sobre los modos de vida de los primeros habitantes de la región rioplatense, la presentación de imágenes sobre el trabajo arqueológico en la prensa gráfica y la exhibición de la vida prehistórica en museos y proyectos de parques temáticos. A través de estos casos analizamos los mecanismos que operaron en la construcción y circulación de saberes sobre arqueología en diferentes contextos y para audiencias diversas. El estudio de la visualidad desde su condición de imágenes-artefactos, esto es, por su carácter material y representacional, nos permite problematizar las relaciones que los grupos sociales han tenido con la creación y promoción de saberes en torno a los tiempos y modos de vida pretéritos.
\end{abstract}

Palabras clave: Popularización de las ciencias; Dispositivos visuales; Arqueología prehistórica

\begin{abstract}
This article aims to analyze the popularization of prehistoric archeology in Argentina at the beginning of the 20th century, based on the study of visual devices created and used to present knowledge about the origin and evolution of man. To this end, we present three examples of the forms acquired by this knowledge and the practices associated with its study: the visual course of the explanatory hypotheses about the ways of life of the first inhabitants of the Rí de La Plata region, the presentation of images about the archaeological work in the graphic press and the exhibition of prehistoric life in museums and theme park projects. Through these cases we analyze the mechanisms that operated in the construction and circulation of knowledge about archeology in different contexts and for diverse audiences. The study of visuality from its condition of images-artifacts, that is, due to its material and representational nature, allows us to problematize the relationships that social groups have had with the creation and promotion of knowledge around times and ways of life in the past.
\end{abstract}

Keywords: Science popularization; Visual devices; Prehistoric archaeology

Desde mediados del siglo XIX se fueron haciendo cada vez más frecuentes los hallazgos y estudios de materiales prehistóricos. Las canteras en el valle del río Somme al norte de Francia, o las cuevas en la región de Suffolk en el sur de Inglaterra, fueron dos de los principales sitios que proveyeron las primeras evidencias sobre la alta antigüedad de la presencia humana en el continente europeo (Hurel y Coye 2011). Con el transcurso de los años, se sumaron sus restos físicos y los de sus antecesores como parte de las discusiones. Estos hallazgos pusieron en tensión las temporalidades hasta ese momento más conocidas y aceptadas para explicar el origen y la evolución de nuestra especie (Gamble y Kruszynski 2009). De la mano del desarrollo de nuevos métodos de trabajo en geología, paleontología y anticuarismo, esas prácticas fueron fundantes de los estudios prehistóricos, 
articulando espacios y saberes diversos y dispersos (Goodrum 2009 y 2014, O’Connor 2007).

En la Argentina el desarrollo de la arqueología prehistórica comenzó en la década de 1860, con la institucionalización de sus prácticas a través de la creación de museos, cátedras universitarias y sociedades científicas (Podgorny 2009). Coincidiendo con el contexto internacional, uno de sus primeros temas fue el estudio sistemático de materiales arqueológicos y paleontológicos que permitían discutir el origen y la antigüedad de las ocupaciones humanas, especialmente en la región pampeana. Conocido como el problema de la antigüedad del hombre, estos debates se iniciaron con los estudios de Florentino Ameghino (i1854?-1911), quien, analizando los materiales encontrados en los sitios de la cuenca del rio Luján, confirmó la coexistencia de los hombres con fauna extinta. Esas evidencias incluían objetos confeccionados en piedra, huesos de animales fósiles con marcas de trabajo humano y restos de fogones. Todos estos eran materiales que él mismo había recolectado, conservando parte de la información estratigráfica relevante para problematizar la antigüedad geológica. A partir de la década de 1890, en el marco de los estudios sobre el origen y la distribución de mamíferos en la Patagonia, los planteos de Ameghino se orientaron hacia la demostración de la ocupación terciaria de los terrenos pampeanos, así como la posibilidad de un origen local para el surgimiento y desarrollo de nuestra especie (Podgorny 2015).

Sin embargo, estas propuestas no fueron aceptadas fácilmente. Las críticas versaban sobre la idoneidad de los voceros, la correcta lectura e interpretación de la antigüedad geológica de los suelos pampeanos y los modos en los que eran presentadas las evidencias. En efecto, muchas veces el centro de la discusión era la propia condición de la evidencia por la calidad de las imágenes con las que eran representadas. Recordemos que las prácticas de la nueva disciplina incluían actividades vinculadas con la producción y uso de materiales visuales. Por medio de ilustraciones, fotografías o calcos se vehiculizaban nuevos conocimientos, métodos de trabajo, potenciales evidencias y registros de actividades o de materiales que circulaban entre los especialistas a través de publicaciones periódicas, actas de congresos, catálogos de museos o libros de síntesis (Moser y Smiles 2005). Pero también, y al ritmo de la propia producción científica, la comunicación en imágenes se extendió a mayores audiencias. La fascinación por la vida prehistórica y los trabajos de los arqueólogos en el terreno se volvieron temas recurrentes en la prensa gráfica, los textos escolares y la literatura de ficción (Moser 1998, Rudwick 1992, Ruiz Zapatero 1997).

En este trabajo nos proponemos abordar la popularización de la arqueología prehistórica en la Argentina durante su etapa formativa (1860-1920), tomando como eje el estudio de los dispositivos visuales asociados al problema de la antigüedad del hombre. Para ello presentamos tres ejemplos en los que analizamos las formas que adquirieron los saberes y las prácticas disciplinares: el derrotero visual de las hipótesis explicativas en torno a los modos de vida de los primeros habitantes de la región, la presentación de imágenes sobre las prácticas del quehacer científico en la prensa gráfica y los modos de exhibición de la vida prehistórica en museos y proyectos de parques temáticos. A través de estos casos indagamos en los modos en los que los saberes se construyen y circulan bajo la condición de imágenes-artefactos en diferentes contextos y entre diferentes audiencias. El estudio de la visualidad, en su carácter material y representacional, nos permite problematizar los modos en los que los distintos grupos sociales han creado y promovido saberes en torno a los tiempos pretéritos.

\section{La casa del gran tatú: una hipótesis como imagen mental y su derrotero material en dispositivos visuales}

En la galería central del Museo de La Plata al día de hoy se conserva el mural "Descuartizando un gliptodonte". Esta pintura al óleo de gran tamaño fue realizada por Luiggi De Servi como un encargo para decorar la rotonda central del nuevo edificio que se inauguró en 1889 (Figura 1). La temática elegida por este artista toscano remite a una escena en la vida cotidiana de un grupo de hombres y mujeres en la prehistoria pampeana. Lejos de ser una licencia poética del artista, sus elementos compositivos y el desarrollo de la acción contenida se nutrieron de las ideas científicas de la época: la confirmación de las personas coexistiendo con fauna extinta. También se trata de la representación de las hipótesis explicativas formuladas por Ameghino respecto del uso de las corazas de gliptodonte como viviendas en la prehistoria pampeana. Esta última idea fue original en su trabajo y, posiblemente, se basó en las interpretaciones sobre el modo de vida de los hombres y mujeres del Paleolítico en Europa.

Brevemente recordemos que Ameghino participó de la Exposición Universal de París en 1879, presentando sus colecciones paleontológicas y arqueológicas a la comunidad científica internacional en algunos de los congresos celebrados en el marco de esa feria. Allí discutió la calidad de los materiales como evidencias de la cohabitación humana con fauna extinta, publicando los resultados en diferentes revistas especializadas, actas y memorias de congresos y el libro de síntesis $L a$ antigüedad del hombre en el Plata. En esas publicaciones, además de presentar sus resultados y los métodos de trabajo, Ameghino explicó el modo en que había sido la subsistencia humana en las planicies pampeanas en los tiempos prehistóricos, ya que se trataba de una región sin cuevas o aleros rocosos que pudiera garantizarla (Ameghino 1879 a y b). Para desarrollar esa línea argumental se apoyó en la descripción minuciosa de 


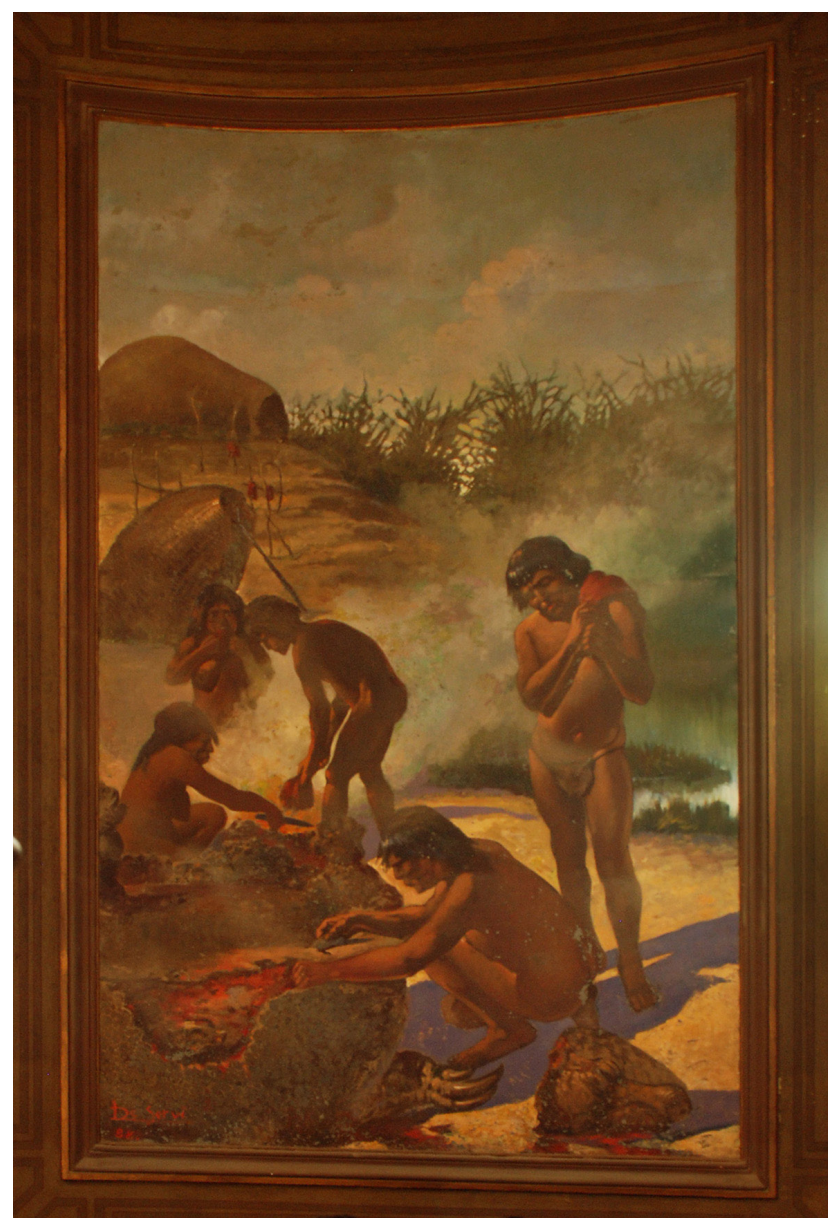

Figura 1. Representación pictórica de una hipótesis explicativa. "Descuartizando un gliptodonte", óleo mural pintado sobre tela y adherido a chapa zinc. Realizado por Luiggi de Servi entre 1888 y 1889. Rotonda central de Museo de La Plata.

Figure 1. Pictorial representation of an explanatory hypothesis. "Descuartizando un gliptodonte", mural oil painted on canvas and adhered to zinc sheet. Made by Luiggi de Servi between 1888 and 1889. Central roundabout of La Plata Museum.

las prácticas de campo, especialmente la manera en la que había encontrado y extraído las grandes corazas de gliptodontes, describiendo la posición original, los sedimentos que las contenían y los materiales que aparecían asociados. Esto último era interpretado como confirmación de un uso habitacional, dado que se trataba de restos de la vida cotidiana de esas personas, como utensilios, deshechos de alimentos o de fogones (Ameghino 1879b: 247).

Ameghino repitió esa lógica de argumentación en su obra de síntesis La antigüedad del hombre en el Plata (1880-1881), esta vez agregando más detalles, como las diferentes formas en las que se ubicaban las corazas en relación con el suelo y con el paisaje. En ese sentido indicaba que los caparazones solían aparecer en grupos, con diferentes grados de inclinación respecto del suelo y cercanos a cursos de agua, marcando cierta analogía con las tolderías.

Volviendo sobre las imágenes del mural del Museo de La Plata, resulta clara la materializaron de esas hipótesis explicativas. Sobre el fondo se puede notar que las corazas fueron dispuestas de acuerdo con las referencias que Ameghino dio en base a los contextos de hallazgo: apoyadas sobre el suelo o sostenidas por postes y próximas a un espejo de agua. De igual modo funcionó la representación de la faena y la cocción del animal, propuesto sobre la base de los restos de huesos carbonizados, especialmente las placas de la coraza, y de algunos objetos de piedra.

Una lectura formal sobre la pintura da cuenta de que esas hipótesis y las evidencias quedaron integradas a las convenciones estilísticas de la representación pictórica de la época. ${ }^{1}$ Se puede notar en el tratamiento de las figuras humanas, especialmente la pose del individuo parado en primer plano de la imagen. El contexto natural operaba en el mismo sentido por el efecto del humo del fogón difuminándose sobre el agua, y los colores elegidos para representar un cielo bucólico característico del atardecer. ${ }^{2}$

Para el museo platense De Servi también había realizado una serie de retratos al óleo de menor tamaño, tomando como temática la fisionomía de las poblaciones indígenas. Esas representaciones fueron encargadas por el director de la institución, Francisco Moreno, para describir y presentar los diferentes tipos raciales (Farro, 2009 y Malosetti y Burucúa 2011). Esas imágenes, junto con las series de esqueletos montados, las fotografías, las mascarillas de yeso y otras pinturas, eran dispositivos de representación visual, desarrollados para favorecer la exposición y la organización de las colecciones del museo (Farro 2009 y 2012). El mural Descuartizando a un gliptodonte se integraba al conjunto de pinturas de gran y pequeño tamaño con las que se decoraron las rotondas del museo, reproduciendo "escenas de la naturaleza Argentina y restauraciones de la vida humana indíjena salvaje..." (Moreno1890-1891: 42). Todas, en diálogo con los objetos exhibidos en las vitrinas y los grandes esqueletos armados en las salas, buscaban causar impresión en el público visitante.

Esa atmósfera también fue registrada por el cronista

\footnotetext{
${ }^{1}$ De Servi, quien se había formado en el Instituto de Bellas Artes de la ciudad de Lucca, puede inscribirse como exponente de la tradición del gran arte decorativo a la italiana, característico de la pintura en la Argentina hacia finales de siglo XIX. Trabajó por encargo de los gobiernos nacional y de la provincia de Buenos Aires en diferentes obras. Entre estas se destaca la serie de retratos de los gobernadores de la provincia de Buenos Aires, realizados con motivo de la creación de la ciudad capital en La Plata en 1887; así como la decoración del techo del Salón blanco de la Casa Rosada para el Centenario de la Revolución de Mayo (Malosetti Costa y Burucúa 2011).

2 Para un análisis de los murales del Museo de La Plata, ver: Carden 2005 y 2009
} 
Enrique Herrero Ducloux, en un artículo de página completa en el diario La Prensa (Figura 2). Junto a las imágenes, en el texto describió:

"En el hall, las figuras de los cuadros que representan escenas de otras edades, parecían adquirir en la penumbra nueva vida, mientras el gigantesco cráneo de la ballena de Mira Mar traía a la mente el recuerdo de las leyendas bíblicas. Mis pasos resonaban en silencio, repetidos por los ecos, como bajo las naves de un templo solitario: envuelto en la oscuridad creciente, sintiéndome solo en aquel mundo de despojos, de imágenes, de cosas que palpitaron en otro tiempo [...] un enjambre de ideas dormidas despertó en mi mente y me pareció que todo á mi alrededor me hablaba en un lenguaje mudo. El ambiente obró sobre mi ánimo predispuesto, el raciocinio dejó su lugar á la imaginación..." (Herrero Ducloux 1907).

De acuerdo con la reseña, el carácter escenográfico de las salas, por sus luces y los objetos e imágenes exhibidos, favorecía la imaginación de los asistentes. La experiencia de transitar y de sentir la vida natural y cultural de la prehistoria se abría paso entre los saberes que se estaban produciendo en el museo, a modo de narrativa visual. La teatralización de la vida prehistórica en las exhibiciones museográficas fue una práctica recurrente en Europa y en los Estados Unidos, diseñada para generar sensaciones visuales y sonoras con carácter de entretenimiento (Rudwick 1992, Moser 1998, Eskildsen 2012).

Herrero Ducloux compartía sus experiencias con los lectores a través de la publicación de una serie de fotografías. Eso era posible por las nuevas técnicas de impresión fotomecánica, especialmente el medio tono, que permitía diagramar la página del diario integrando las imágenes al texto. ${ }^{3}$ Por su tamaño y ubicación en la hoja del diario esas fotos, más que decorar el texto, constituían un relato en sí mismas, reconstruyendo el recorrido que el cronista había hecho durante su visita al museo: la vista exterior del edificio, el hall central y algunas de las salas con materiales, especialmente las reconstrucciones de los gigantes fósiles.

Entre esas imágenes llama la atención la figura que llevaba el título de El jorobado: un montaje de la vista de perfil de un esqueleto, columna y cráneo, con una importante singularidad en la región cervical (extremo inferior izquierdo de la Figura 2). En el texto Herrero Ducloux no daba referencias sobre la pieza, pero su elección permite pensar en un guiño, exclusivo relato visual, del

\footnotetext{
3 Se trata de un sistema de reproducción fotomecánica en el que se genera una trama en puntos a partir de una imagen fotográfica, sin necesidad de traspasar la imagen del negativo a un soporte. Se trabaja directamente sobre la impresión, permitiendo ubicar la trama en la prensa tipográfica (Tell 2009).
}

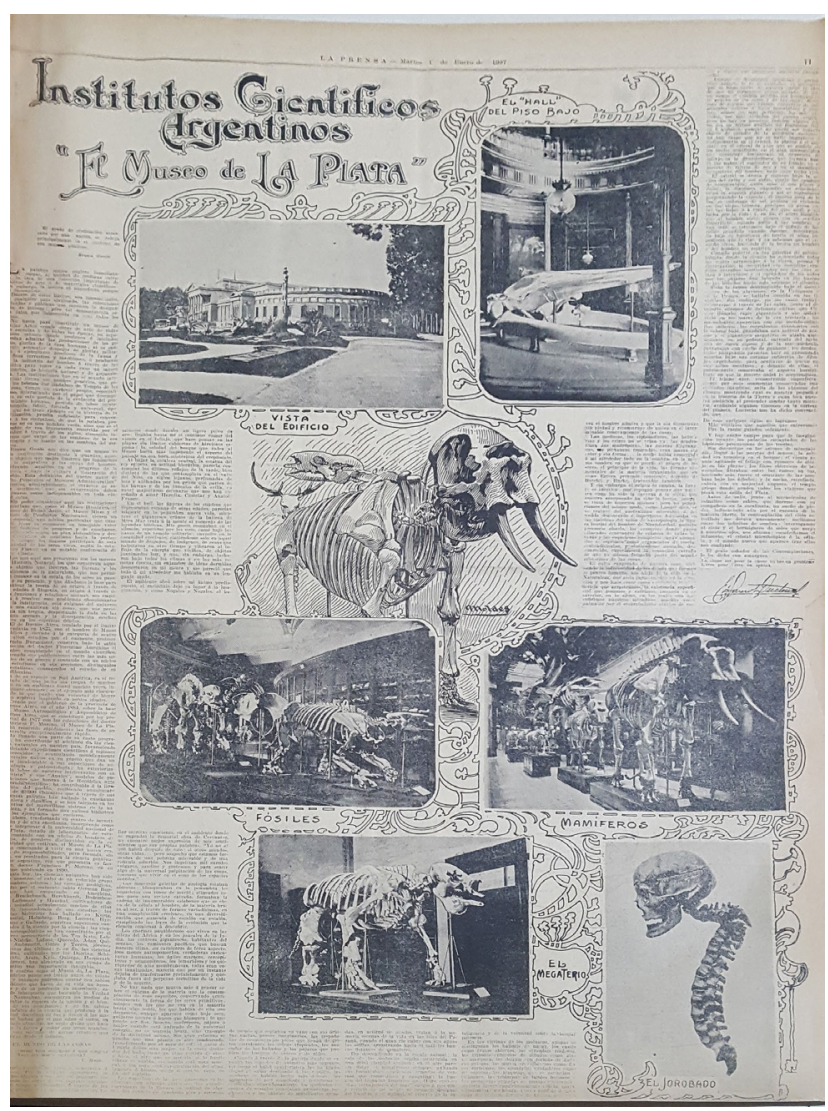

Figura 2. Fotografías del Museo de La Plata en la prensa diaria. Nota de Enrique Herrero Ducloux para el diario La Prensa, 1 de enero de 1907.

Figura 2. Photographs of the La Plata Museum in the daily press. Note by Enrique Herrero Ducloux for the newspaper $L a$ Prensa, January 1, 1907.

controversial atlas de Monte Hermoso. Las discusiones en torno a esta pieza se vinculaban tanto con la antigüedad y la historia de los trabajos en el sitio de Monte Hermoso como con las características propias del material. Todo esto en un contexto de disputas institucionales entre los museos Nacional de Historia Natural de Buenos Aires y de La Plata hacia comienzos del siglo XX.

El material en cuestión, una vértebra cervical, había sido interpretada como evidencia física de los precursores humanos debido a su tamaño y forma, excéntricos para la anatomía de un humano moderno. El sitio del cual provenía la pieza, ubicado en el sudoeste de la costa bonaerense, había sido descubierto en 1887. Desde esas primeras exploraciones participó en las discusiones sobre la antigüedad del hombre, a partir de los restos de tierra cocida y de materiales líticos que fueron interpretados por Ameghino como vestigios de actividades humanas intencionales. A partir de 1906, a esas evidencias se sumaron dos restos físicos, la mencionada vértebra cervical y parte de un fémur. Para Ameghino, entonces director del Museo Nacional, ambos huesos correspondían al género Tetraprothomo argentinus, uno de los precursores 
humanos que había descripto previamente y como modelo ideal en su trabajo Filogenia (Ameghino 1884). Por su parte, Robert Lehmann-Nitsche (1872-1938) a cargo de la sección de Antropología del Museo de La Plata utilizó aquella vértebra para definir una nueva especie dentro del género Homo: el Homo neogaeus (Lehmann-Nitsche 1907).

Retomando la hipótesis de Ameghino sobre la casa del gran tatú, esta no se agotó en el mural del museo. Años más tarde la pintura fue reproducida en Los Aborígenes de la República Argentina, un manual escolar escrito por los profesores de la Universidad de La Plata Félix Outes y Carlos Bruch. En el prefacio los autores insistían en la importancia y el caudal de imágenes presentes en el libro, en su mayoría fotografías de las colecciones del Museo de La Plata, como documentos iconográficos de los habitantes prehistóricos de la Argentina (Outes y Bruch 1910: 5).

En esta oportunidad se trató de la reproducción fotográfica, en blanco y negro, ocupando la página completa. La imagen era presentada como un soporte visual para las descripciones de los restos arqueológicos encontrados en el Piso Bonaerense de la Formación Pampeana, caracterizando los modos de vida en la prehistoria de acuerdo con las conclusiones originales de Ameghino (Outes y Bruch 1910: 44). La misma información se repetía en el pie de imagen en la que también se incluía la autoría del mural y el lugar en el que se encontraba exhibido, las galerías del museo.

Las hipótesis explicativas de Ameghino, como imágenesideas sobre los modos de vida de los hombres en la prehistoria, tomaron forma visual a través de diferentes dispositivos. La materialidad y los contenidos representados se fueron modificando en relación con los contextos en los que se exhibían, atendiendo a la variedad de sujetos que accedían a estas imágenes como visitantes del museo, lectores de noticias o alumnos y docentes de las escuelas.

\section{¡Extra, extra! Estudiosos, objetos y prácticas en la prensa periódica}

La prensa periódica ha sido un canal preponderante para el desarrollo de la arqueología prehistórica desde sus inicios, tanto en la Argentina como a nivel internacional. A través de los medios gráficos se han visibilizado y legitimado las diferentes prácticas que hacen a esta ciencia, permitiendo dar cuenta del carácter co-constructivo que el conocimiento asume entre los diferentes grupos sociales (Sommer 2006). Las noticias sobre nuevos descubrimientos, las discusiones entre estudiosos o la promoción del patrimonio fueron algunos de los temas con los que la arqueología prehistórica fue presentada en los diarios nacionales (Podgorny 2009 y 2016).
La figura de Ameghino es un caso interesante para estudiar, ya que da cuenta de la importancia que los medios tuvieron para legitimar sus estudios sobre la antigüedad de las ocupaciones humanas así como favorecer la construcción de su imagen como un sabio incomprendido o "santo laico" (Podgorny 1997). Un ejemplo es la nota que publicó el semanario ilustrado Caras y Caretas con motivo de su designación como director del Museo Nacional de Buenos Aires en abril 1902 ("El nuevo director del Museo Nacional" 26 de abril de 1902). Como era característico de esta publicación, se destacaba lo visual por sobre el texto, en este caso a través de tres fotografías ubicadas en el centro de la hoja (Figura 3). Las imágenes en sí mismas y en diálogo con el contenido escrito de la nota, favorecían una valoración positiva de Ameghino en sus funciones de investigador y de director del museo, destacándose la importancia de las colecciones y las prácticas asociadas a su catalogación, estudio y cuidado ("El nuevo director del Museo Nacional"

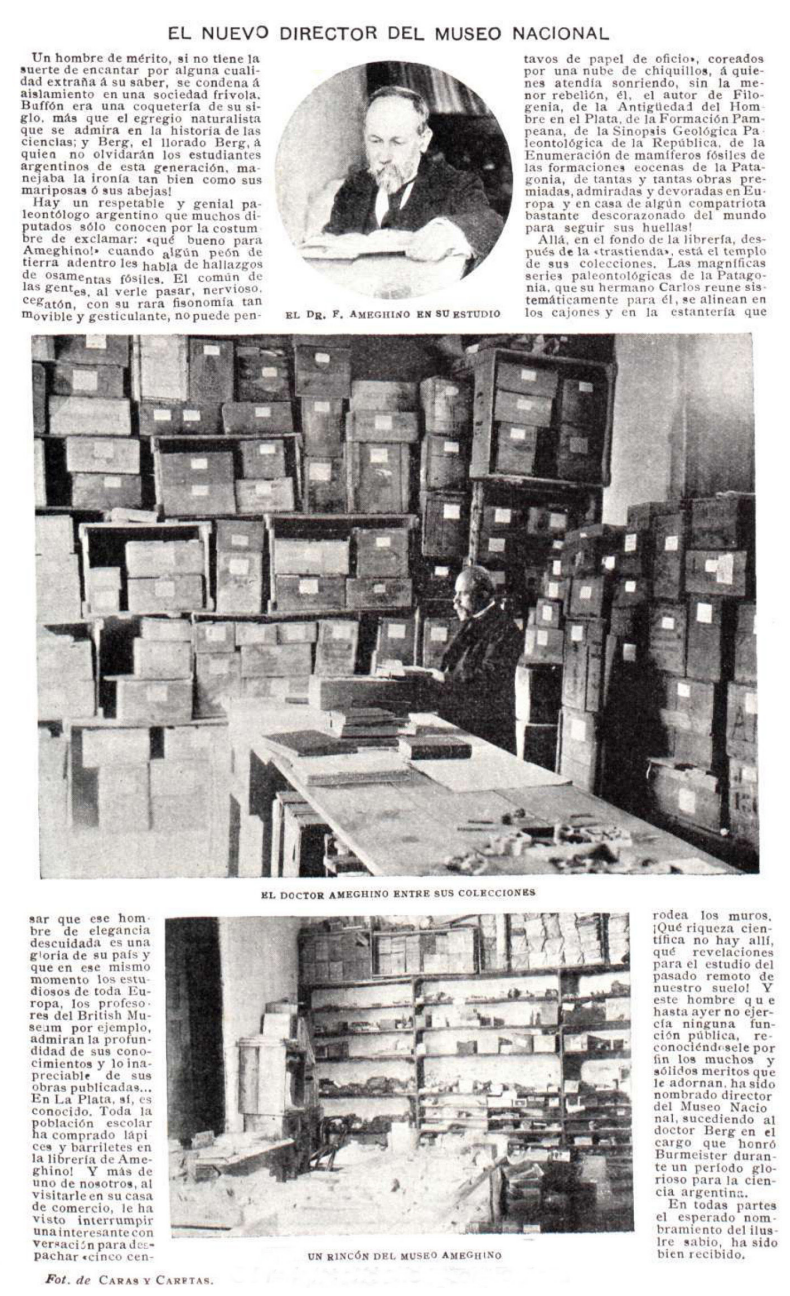

Figura 3. Florentino Ameghino en la prensa ilustrada. "El nuevo director del Museo Nacional", Caras y Caretas V (188), Buenos Aires, 26 de abril de 1902.

Figura 3. Florentino Ameghino in the illustrated press. "The new director of the National Museum", Caras y Caretas V(188), Buenos Aires, April 26, 1902. 


\section{6 de abril de 1902).}

Esos mismos elementos volvían a aparecer en el número de mayo del mismo año, como parte de la sección Caricaturas contemporáneas que José María Cao ilustraba para Caras y Caretas (Figura 4). ${ }^{4}$ Ameghino era la figura central de la escena, estudiando con una lupa los restos de un animal antediluviano. Un ejemplar bastante exótico, montaje de diversas partes anatómicas de distintos animales. La caricatura llevaba un pequeño texto que rimaba:

“De la mayoría se cumplió el deseo y Ameghino á gusto cuida del museo, donde piensa ahora que los animales antediluvianos crezcan y se críen sólidos y sanos en la incubadora" ("Caricaturas contemporáneas" 17 de mayo de 1902).

La cita parece indicar dos cuestiones asociadas a la popularización satirizada de la figura de Ameghino y su trabajo. En principio se resolvía la expectativa de la revista del número de abril y del propio Ameghino, ser el Director del Museo Nacional, lo que significaba trabajar desde la "institucionalidad." Lo hacía, siguiendo el verso, cuidando de la fauna extinta ilustrada en las cajas ordenadas con etiquetas, una colección clasificada, como ya lo había hecho en su casa-comercio de La Plata, tal como lo atestiguaban las fotografías del número de abril. Ameghino caricatura, "piensa ahora" en esos animales que van a tomar el cuerpo de sus teorías, quizás favorecidos por la incubación. Pero también el estudioso era representado en la práctica de analizar materiales, una de las principales formas corporales que asumía la mirada científica, en este caso dibujada con la paciencia y la lupa. ${ }^{5}$

A esa praxis visual se sumaban las fotos en las que posaba como lector. ${ }^{6}$ Un ejemplo interesante encontramos en una nota de 1917 de Caras y Caretas en conmemoración del sexto aniversario del fallecimiento de Ameghino (Figura 5). Si observamos con atención, en la foto superior se registra la acción de mirar imágenes. Ameghino está sentado en un sillón y sostiene un libro parecido a un catálogo o atlas ilustrado.

El uso de materiales visuales impresos era una práctica

\footnotetext{
4 Para un análisis de los trabajos del dibujante en la prensa periódica y una lectura de esa caricatura en relación con las ideas científicas de Ameghino y el positivismo, ver: Szir 2011.

5 Sobre la mirada como práctica científica, se puede encontrar una primera aproximación en la tesis de la autora, quien se encuentra trabajando en una investigación más detallada al respecto (Simón 2018a).

${ }^{6}$ Este tipo de imagen era bastante frecuente encontrándose ejemplos en el retrato de la Sociedad Científica que mencionamos y en otras notas como El Diario ("El Museo de Historia Natural en peligro de derrumbe. Reportaje al Dr. Ameghino" 23 de julio de 1904) y Caras y Caretas ("Centenario del Museo Nacional 8 de junio de 1912).
}

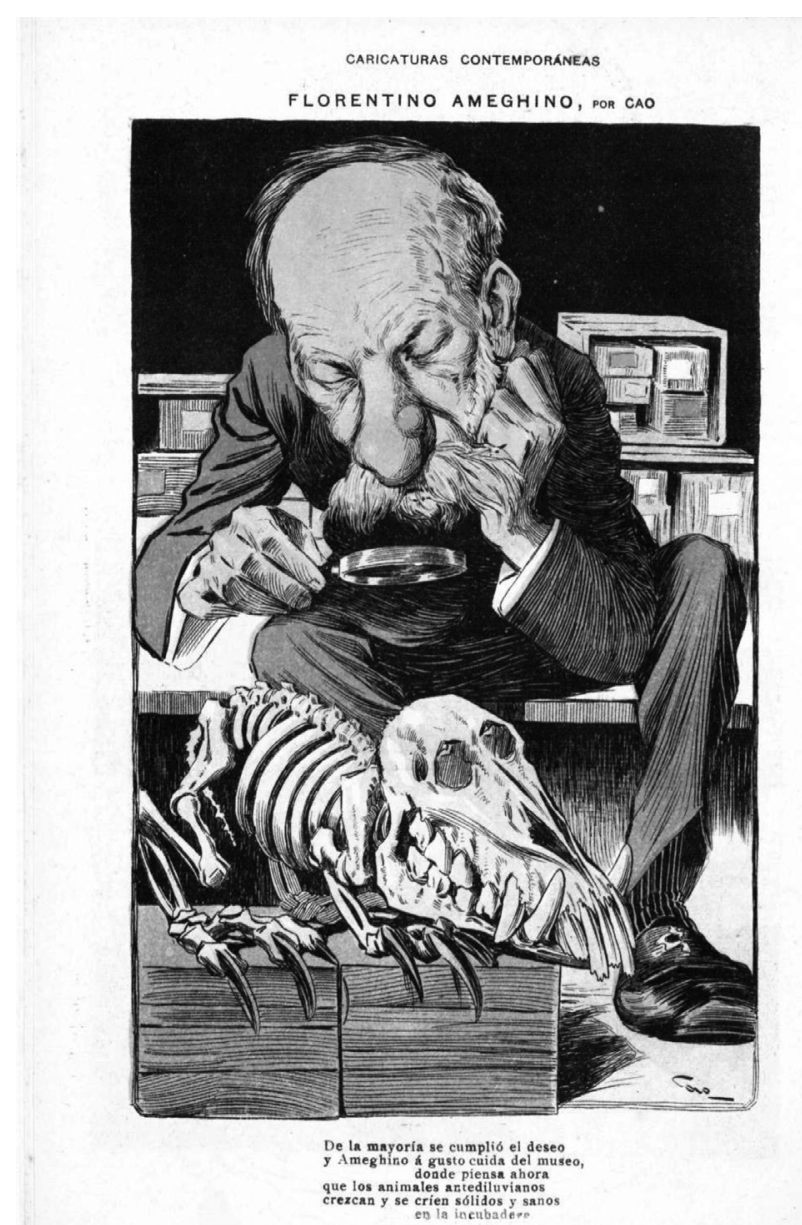

Figura 4. Caricatura de Florentino Ameghino con sus colecciones. Dibujo a color realizado por José María Cao. "Caricaturas contemporáneas", Caras y Caretas V (189), 17 de mayo 1902

Figura 4. Caricature of Florentino Ameghino with his collections. Color drawing by José María Cao. "Contemporary caricatures", Caras y Caretas V (189), May 17, 1902.

muy frecuente en los estudios en ciencias naturales ya que favorecía la portabilidad de los especímenes para analizar, rocas, plantas o huesos, ampliando su circulación y uso entre especialistas de diferentes lugares (Rudwick 2000). Era condición que las imágenes fueran de calidad, bien ejecutadas y fieles al original, lo que implicaba ciertos conocimientos y atención de los procesos de producción y reproducción de imágenes (Simón 2018a y b). En el mismo sentido, los debates entre los estudiosos también versaron sobre la calidad de las imágenes que publicaban, usando criterios de corte estético visual para poner en cuestión los postulados e ideas de sus colegas (Simón 2018a y b). ${ }^{7}$

Con los ejemplos señalados anteriormente buscamos

\footnotetext{
7 Tal fue el caso de las querellas entre Florentino Ameghino y Hermann Burmeister por la calidad de los materiales que producían, ejemplificando cada uno de ellos tradiciones visuales diferentes de acuerdo con el estado de las tecnologías de producción y reproducción de imágenes imperantes. Para un análisis detallado, ver: Simón 2018 b.
} 


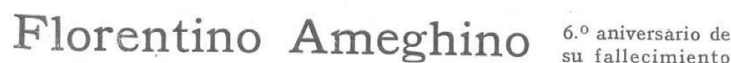
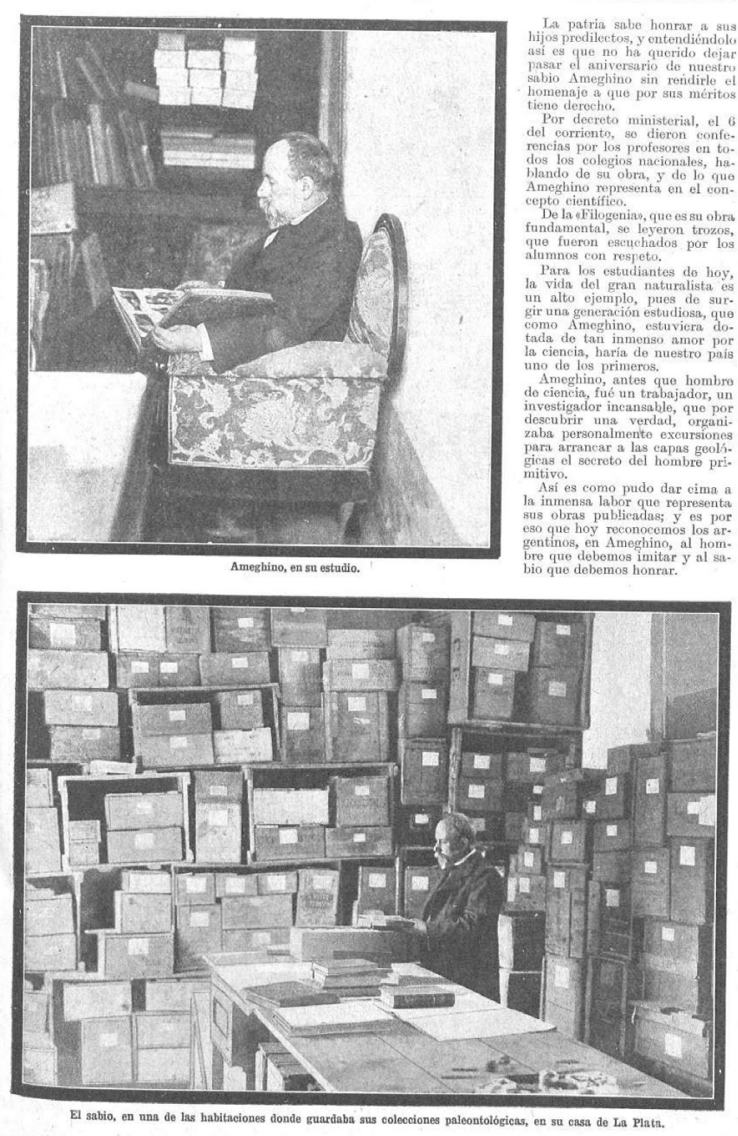

Figura 5. Representación de Florentino Ameghino en la prensa ilustrada. Publicada en "Florentino Ameghino. 6to año de su fallecimiento", Caras y Caretas (985), 18 de agosto de 1917.

Figura 5. Picture of Florentino Ameghino in the illustrated press. Published in "Florentino Ameghino. 6th year of his death", Caras y Caretas (985), August 18, 1917.

problematizar el rol de las imágenes como dispositivos empleados por la prensa gráfica para la popularización científica. La figura de Ameghino operó en ese sentido al ser presentado en actitud de trabajo. A diferencia de las notas en los diarios, donde el texto predominaba ampliamente, en Caras y Caretas el relato visual explicitaba las prácticas de investigación asociadas a los modos de ver.

Otro elemento que se desprende de los ejemplos analizados en esa publicación es la referencia a los creadores de las imágenes. Esos datos aparecieron en "Caricaturas contemporáneas", como dijimos a cargo de Cao, y en la nota "El nuevo director..." donde se indicaba que las fotografías pertenecían a la revista (Caras y Caretas 26 de abril de 1925). El dato inscripto en la materialidad de la revista se hacía extensivo a las reutilizaciones subsiguientes, especialmente en la nota por la conmemoración del fallecimiento de
Ameghino. Es posible que la revista haya realizado la serie de fotografías en 1902 y que las reutilizara en sus sucesivas notas. Más allá de ese detalle, lo que destacamos de la publicación es el impacto de la transformación tecnológica en la cultura visual, a través de la mecanización en la producción y reproducción de imágenes. Caras y Caretas contaba con su propio taller y con fotógrafos encargados de realizar de muchas de las imágenes que se publicaban en sus páginas. ${ }^{8}$

Otro de los temas expuestos en la prensa fue la comunicación de los hallazgos de materiales arqueológicos en los sitios cercanos a la localidad de Miramar en la costa bonaerense. En las primeras décadas del siglo XX esas noticias crecieron significativamente, haciendo que el debate por los antecesores humanos formara parte de la actualidad periodística. Más allá de informar o discutir la autenticidad de las piezas, en las notas se destacaba la importancia que esos descubrimientos tenían para el conjunto de la nación, instando a que el Estado aportara recursos para continuar las exploraciones (Bonomo 2002).

Especialmente nos interesa analizar el contenido visual de algunos de esos artículos y su cualidad de dispositivos para la popularización de saberes y prácticas científicas. Así, en el diario La Nación del $1^{\circ}$ de diciembre de 1913 se publicaron tres fotografías que ilustraban el sitio de Miramar y el material en su contexto original. Se trataba del registro de las prácticas desarrolladas por la comisión de especialistas del Museo Nacional de Buenos Aires y de la Universidad de La Plata, con el objetivo de certificar la veracidad de un hallazgo, una bola adherida al sedimento original en el barranco costero. Como dispositivo visual, era un hibrido entre aparato de certificación del trabajo científico y material impreso en una calidad regular para un diario de tirada masiva.

Las mismas fotografías se volvieron a publicar por esos días en el semanario Caras y Caretas, en un artículo escrito por Lehmann-Nitsche en el que abordó la cuestión de los antecesores humanos, explicando las noticias referidas a los materiales encontrados en Miramar (Figura 6). Las imágenes ocupaban un espacio destacado en la página y armaban una narrativa visual a través de su disposición y encuadre. El tema en las tres fotos era el conjunto sedimento-material, motivo de la aparente autenticidad y antigüedad de la pieza, a la vez que de la campaña realizada por la comisión de especialistas. En el centro de la página una imagen del detalle de la bola adherida al sedimento y en las otras dos de las vistas panorámicas de la barranca y la costa con la indicación del punto de remoción. La presencia de personas en una de las fotos funcionaba como escala para reponer las dimensiones del espacio, a la vez que eran testigos de la práctica en el sitio y del hallazgo. ${ }^{9}$

\footnotetext{
${ }^{8}$ Sobre la producción de fotografías en Caras y Caretas, su circulación, consumo y utilización, ver: Tell 2009, Szir 2009 y 2013.

${ }^{9}$ Esta última imagen, su contenido representacional, fue característico
} 
estar asociado al desarrollo de una mirada que se iba modelando y familiarizando con la interpretación de la evidencia arqueológica en su dimensión visual.
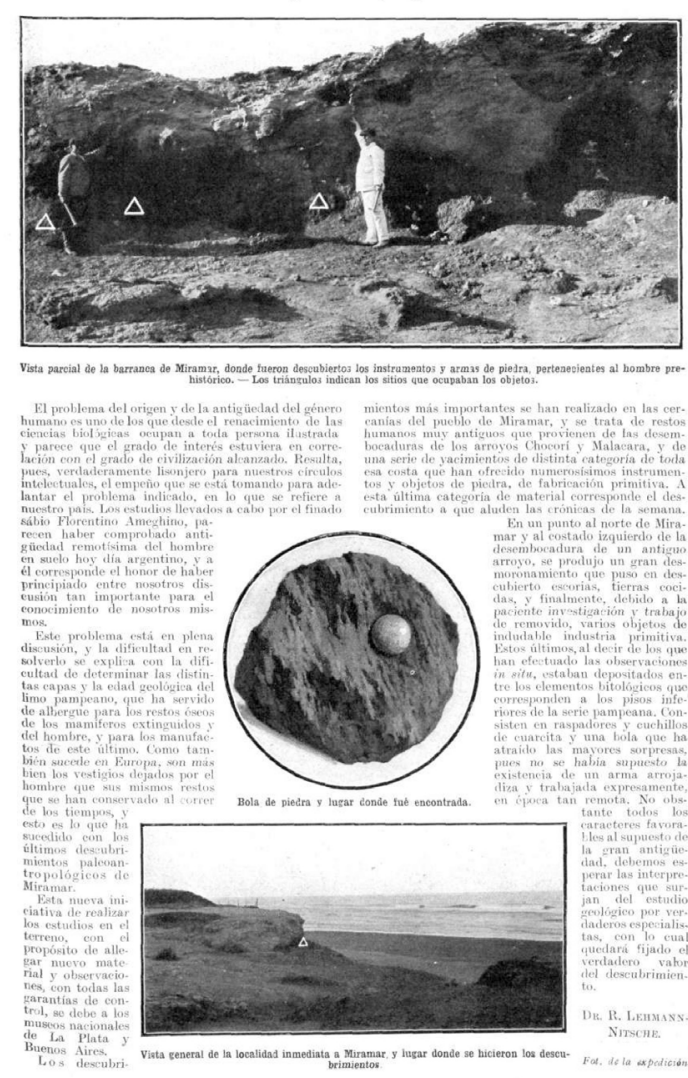

Figura 6. Registro de prácticas de campo en la prensa ilustrada. Las fotografías fueron realizadas durante la expedición. Publicada por LEHMANN-NITSCHE, Robert "Descubrimientos paleoantropológicos en Miramar", Caras y Caretas XVI (793), 13 de diciembre de 1913.

Figura 6. Field practices in the illustrated press. The photographs were taken during the expedition. Published by LEHMANNNITSCHE, Robert "Paleoanthropological discoveries in Miramar", Caras y Caretas XVI (793), December 13, 1913.

Las imágenes publicadas en La Nación y Caras y Caretas fueron intervenidas por medio del dibujo de marcas, una cruz y un triángulo, como forma de indicar el lugar al que el observador debía prestar atención. Ese detalle era un retoque hecho sobre el soporte y una forma de completar el contenido visual para favorecer la comprensión de la imagen. Se trataba de una estrategia frecuente en las fotografías de las publicaciones científicas. Especialmente en aquellas sobre las descripciones de sitios y contextos de hallazgos, como parte de los datos geológicos relevados.

El público lector de diarios y revistas estaba interesado en las noticias científicas tanto en el contenido que se escribía como en las imágenes. Esto último podría

de la fotografía arqueológica que se inauguró en 1859 con el registro de las canteras de Saint-Acheul, en Francia. Allí aparecían dos obreros indicando el punto en el que habían extraído un hacha de mano asociada a restos de animales fósiles (Gamble y Kruszynski 2009).
Lo mismo podría decirse de los restos físicos discutidos como posibles antecesores humanos en los debates. El diario La Nación publicó pequeñas ilustraciones de los cráneos de los ejemplares de Homo pampaeus y Homo sinemento, dos individuos descriptos e interpretados por Ameghino como antepasados de los humanos modernos. En relación con el primer caso, la imagen del cráneo fue publicada en una nota de diciembre de 1912 en la que se discutían hallazgos recientes en la región pampeana. Era una ilustración de Homo pampaeus, una figura pequeña, esquemática y simplificada de la fotografía original que Ameghino publicó en su trabajo para los Anales del Museo Nacional en 1909 (Figura 7).

Comparando ambas figuras podemos señalar que el diario publicó la imagen tomando como referencia la fotografía original y respetando las intervenciones realizadas en aquella. Se replicaba la sucesión de líneas que completaban la bóveda craneal, reproduciendo el aspecto plano y deformado del cráneo que lo hacía ver como un ejemplar distinto del hombre moderno. Al conservar esos detalles visuales los lectores podían ver y aprender a reconocer los caracteres especiales, formando su mirada en el entendimiento de esas evidencias. En el mismo sentido funcionaba el texto de la nota, que reparaba en ese detalle anatómico para resaltar su diferencia con un cráneo de humano moderno:

“En cuanto al encuentro de fósiles de nuestro país, que como se ha dicho, no es de un solo tipo, sino de muchos, podemos presentar las fotografías del cráneo del hombre fósil hallado por Ambrosetti en la estancia del señor Guerrero (Banderaló), así como la del homo pampaeus de Ameghino, en las cuales se ve claramente que no se trata de un ser bestializado como el de Neanderthal, o bien Chapelle-auz-Saints, sino de un tipo antecesor genuinamente humano, no solamente muy anterior a ellos, pues es de la capa terciario, sino también de inteligencia superior" ("Notas científicas. El hombre fósil" 25 de diciembre de 1912. Subrayado nuestro).

Algo similar sucedió con la figura de Homo Sinemento en una nota publicada en agosto de 1913. La presentación de tres imágenes de cráneos, se hacía para explicar los hallazgos de Ameghino de 1910, pero también para promover las nuevas exploraciones practicadas en la costa por Luis María Torres (1878-1937) y Carlos Ameghino (1865-1936). Brevemente recordemos que el punto central de esas discusiones era ghhjhnla presencia o ausencia del mentón, entendido como un carácter evolutivo que se había desarrollado en los humanos modernos. Para los hermanos Ameghino en los ejemplares encontrados en los 
Figura 7. Cráneo de Homo pampaeus. Ilustración en la prensa diaria y fotografía original publicada por Ameghino (1909). "Notas científicas: el hombre fósil", La Nación, 25 de diciembre de 1912.

Figure 7. Skull of Homo pampaeus. Illustration in the daily press and original photograph published by Ameghino (1909). "Scientific notes: the fossil man", La Nación, December 25,1912

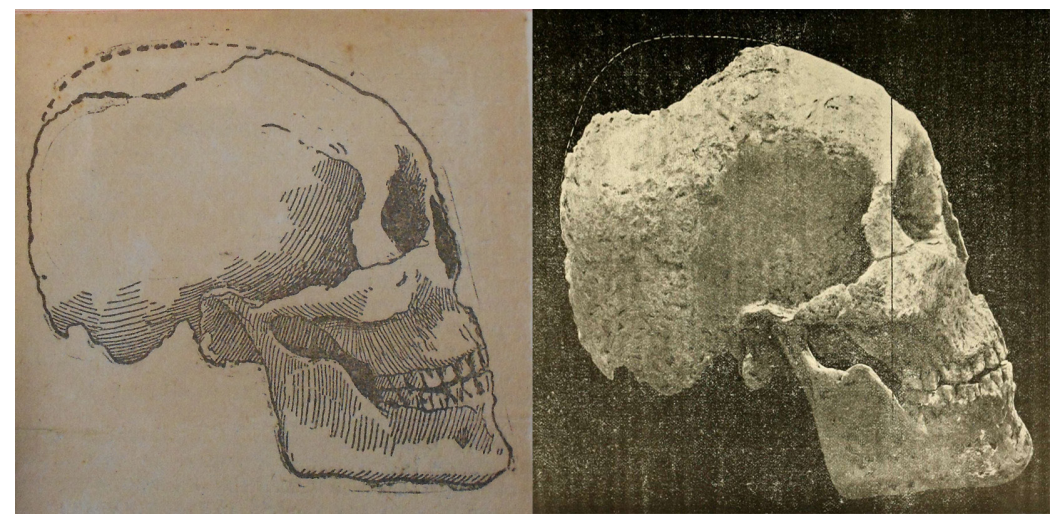

sitios costeros su desarrollo era incipiente, funcionando como evidencia de antecesores humanos.

Toda la información fue explicada en el cuerpo de la noticia acompañada por tres imágenes de distintos cráneos en los que se indicaba con una flecha la parte anatómica discutida. En primer lugar, se presentó la ilustración de un cráneo anatómicamente moderno tomado como modelo. ${ }^{10}$ En seguida explicaban los hallazgos realizados en Europa sobre los antecesores humanos conocidos, dando una nueva imagen con el fin de indicar, "como se ve en nuestro dibujo", la ausencia de aquella prominencia destacada con una flecha. Finalmente se publicaba la imagen de Homo sinemento, encontrado recientemente por Carlos Ameghino quien lo comunicó a los redactores del diario. Al respecto, el diario señalaba que: "Dibujamos enseguida el perfil del cráneo de uno de los esqueletos, marcando con una flecha la ausencia del mentón" ("Notas Científicas. Homo Sinemento" 3 de agosto de 1913). El nuevo dibujo, sin mentón, incorporaba otros rasgos anatómicos que favorecían el desarrollo argumental: "Se ve, pues, la frente elevada y no deprimida, como en "primigenius", se ven las mandíbulas sin prognatismo, no alargadas como hocico de mono, no existen tampoco los bureletes superorbitales y los caninos son cortos" ("Notas Científicas. Homo Sinemento" 3 de agosto de 1913). Esas estrategias discursivas y visuales permitían comprender los argumentos de los estudiosos, quienes trazaban una línea de sucesores que los incluía con nuestra especie. Al formar parte de los contenidos del diario, estas propuestas ganaban notoriedad y posibles adeptos en los debates.

A través de los casos analizados buscamos ejemplificar algunas de las posibles relaciones entre la comunicación pública de la arqueología y la prensa gráfica, como interacciones entre los dispositivos, las técnicas que habilitaron su producción y reproducción y los contenidos

\footnotetext{
10 "En la calavera que presentamos, puede perfectamente verse, indicada por la flecha, la parte saliente de la mandíbula inferior, a la que se ha denominado mentón. Este, desde el punto de vista filogenético, o sea del desarrollo sucesivo del hombre en la historia de la tierra, que poco a poco ha ido perfeccionándose hasta alcanzar su forma actual de "homo sapiens", tiene una gran importancia pues es solamente en los últimos tiempos que ese desarrollo mentoniano se ha producido, y es por lo tanto un carácter típico del hombre ya más perfecto" ("Notas Científicas. Homo Sinemento" 3 de agosto de 1913).
}

o representaciones. Destacamos la co-construcción de saberes con sus mediaciones en personas, publicaciones y aparatos técnicos, a la vez que la repetición en la estrategia de mostrar. En este caso en particular, se trabajaba con un público consumidor para persuadirlo o educarlo en otra forma de apropiación de imágenes que son nuevas pero que mantiene sus referencias con aquellas que circularon en el ámbito académico.

\section{Exposiciones y Proyectos: del color de los charrúas a los parques temáticos}

Otra forma de popularización de la arqueología científica fueron las exposiciones de réplicas a escala de materiales en parques temáticos, plazas o museos, muchas veces creados con el fin de recrear la vida en la prehistoria. Presentamos en este apartado dos ejemplos que, aunque diferentes en épocas y temas, visibilizan los mecanismos para la espectacularización del pasado más remoto, de su flora, fauna y cultura, como parte del atractivo generado en los públicos asistentes y en sus promotores. Esa interacción permite conocer las estrategias que los estudiosos generaban para atraer audiencias y solventar sus prácticas de trabajo.

Un caso interesante se relaciona con el desarrollo de modelados en yeso como recurso científico, didáctico y expositivo de los museos. La producción de estos materiales planteaba dificultades técnicas a la vez que exigía altos estándares de calidad, especialmente en el caso de la reproducción que se utilizaba como referencia en las prácticas de laboratorio. Las diferentes posibilidades de uso, sin embargo, podían generar algunas contradicciones como sucedió con los bustos de los individuos adscriptos a la etnia charrúa y su color de piel, mediados por las distancias temporales, espaciales e interpretativas entre original, los indígenas, y la copia.

Ameghino en su obra La Antigüedad del hombre en el Plata, presentó una pequeña digresión respecto de la filiación étnica de los diferentes grupos que habitaron la región circundante al río de La Plata para explicar las ocupaciones durante el Neolítico. Allí desarrolló sus ideas sobre la adscripción étnica de los Charrúas, más próximos o vinculados con los grupos guaraníes que con los pampas 
y los araucanos como proponían otros autores (Ameghino [1880-1881] 1947: 327). Durante su estancia en Francia, con motivo del Congreso Internacional, realizó una visita junto con otros estudiosos al Jardín de Aclimatación. En las galerías estaban exhibidos los bustos en yeso que representaban indígenas charrúas, dos pintados en negro y un tercero de color más rojizo, considerado por el museo como un ejemplar de un individuo mestizo (Ameghino [1880-1881] 1947: 327). Las tres réplicas habían sido realizadas a partir de modelos vivos, llevados especialmente a Paris para su exhibición. Esa información le fue dada por Paul Topinard y Paul Broca, quienes trabajaban en el laboratorio del museo y conservaban restos epiteliales de los individuos que certificaban el color negro.

Ameghino, sin embargo, dudaba de esas evidencias y presentó nuevos datos para señalar el error asignado a los calcos como auténticos especímenes del grupo. Entre sus fuentes citó los testimonios de los primeros viajeros naturalistas que habían explorado la región en el siglo XVI y los relatos de Alcide d'Orbigny, Paolo Mantegazza y Enrique Giglioli en el siglo XIX. Remarcaba que todos ellos habían estado en la región viendo a los grupos originales, a diferencias de quienes estudiaron los modelos vivos llevados al Jardín. Asimismo daba el testimonio que había obtenido en una entrevista con el ciudadano uruguayo Joaquín Belgrano, quien había conocido a los "verdaderos charrúas" y desconfiaba también de la autenticidad de los moldes que pudo observar en el Jardín.

Ameghino expuso sus motivos para entender por qué los ejemplares exhibidos como charrúas eran ciertamente individuos de "raza negra". Para ello volvió sobre la historia de la conquista en la región, recordando que muchos grupos sociales se habían refugiado en la nación charrúa favoreciendo el mestizaje. Junto con esa historia reconstruyó otra, la del armado de colecciones en el siglo XIX. Así, los pocos individuos que habían sobrevivido a las conquistas fueron elegidos para representar las formas ideales de aquel grupo étnico, explicado por Ameghino en los siguientes términos:

"Los dos bustos del Museo de París representan los dos hombres más oscuros de los tres, y el cuerpo entero representa el tercero, que sin duda por ser de un color mucho más claro que los otros fue considerado mestizo.

Es seguro que quien llevó a Europa a esos infelices no eligió para su especulación sino los que presentaban una fisionomía más extraña y que más se diferenciaba de la de los europeos; y esta presunción tan natural, confirmada por el tipo de los individuos que no representan el de los charrúas, nos hace creer que los individuos llevados a Paris y que representan los dos bustos del Jardín de las Plantas, eran mestizos, resultado de cruzamientos de individuos de esta nación con los negros cimarrones" (Ameghino [1880-1881] 1947: 330).

Los errores advertían las interpretaciones efectuadas sobre la base de una distancia espacial y temporal, tan grande como la que separaba a las poblaciones americanas encontradas y llevadas a Europa después del contacto. En ese sentido, el color de los charrúas implicó también la contemplación de una historia y de sucesivos tiempos que daban a las personas "en sus contextos de hallazgo original" una variabilidad que modificaba cualquier afirmación. Máxime cuando la elección de los tipos ideales para mostrar, se hizo sobre la base de sus transformaciones histórico culturales y del valor por lo exótico para definir un modelo "natural."

Años más tarde esas ideas aparecieron como una imagen, una fotografía impresa en el Manual escolar de Bruch y Outes. Presentada como parte de "Los pueblos históricos del litoral de los grandes ríos", los charrúas fueron descriptos según las áreas que ocupaban y sus caracteres físicos, sociológicos y lingüísticos. La única imagen elegida para representar al grupo provenía de: "Un charrúa exhibido en París en el año 1831, según el busto modelado en el Museo de Historia Natural de aquella capital" (Outes y Bruch 1910: 90). Los autores estando al corriente con los debates sobre las filiaciones étnicas describieron sus caracteres físicos remarcando que: "conviene se tenga en cuenta que la COLORACION de su PIEL se considera una de las más oscuras entre los indígenas sudamericanos" (1910: 90).

La reconstrucción de los modos de vida, ideales o atractivos, de la época prehistórica o prehispánica, como en el ejemplo anterior, no quedó limitada al espacio del museo como mecanismo de popularización de los saberes científicos. Los textos escolares, también incorporaron esas imágenes para ilustrar la vida en el pasado, tal como expusimos respecto del mural de Luiggi De Servi. El desarrollo de parques temáticos operó en el mismo sentido, buscando recrear algo de la vida en el pasado para posibilitar su experimentación. Su análisis confirma que la participación de profesionales en la creación de saberes fue un proceso más amplio e integrado, tensionando el binomio saber científico-saber popular.

Con motivo del aniversario del primer año del fallecimiento de Ameghino, se desarrollaron diferentes proyectos para su conmemoración (Podgorny 1997). La Sociedad Científica Argentina realizó una serie de conferencias sobre la vida y la obra del sabio. En ese contexto exhibieron su retrato, un óleo encargado a De Servi y que en la actualidad decora la sala de actos de la Sociedad (Castro 1912).

Con el mismo propósito, Lehmann-Nitsche diseñó un proyecto para la realización de un parque paleontológico sobre la fauna pampeana que llevaría el nombre de Ameghino (Lehmann-Nitsche 1912). Sin embargo, el 
objetivo real del proyecto, tal como explicaron Ballestero y Sardi (2016), trascendía el valor pedagógico y educativo previsto para el desarrollo de las ciencias antropológicas. Se trataba de un negocio redituable, promovido por Carl Hagenbeck, creador de uno de los más famosos zoológicos de Alemania: Tierpark Hagenbeck. Por las negociaciones de Lehamann-Nitsche, el empresario buscaba que las autoridades aprobaran el proyecto y que el desarrollo lo realizara el artista plástico alemán Josep Pallenberg. Como contrapartida Lehmann-Nitsche podía acceder a la compra de reproducciones paleontológicas y participaba de los trabajos para instalar una sección sobre la Pampa Argentina en el zoológico de Stellingen en Alemania (Ballestero y Sardi 2016). Aunque no prosperó, Lehmann Nitsche hizo gestiones ante el comisionado del Poder Ejecutivo Comunal, Luis María Doyhenard Chilavert, para la aprobación del proyecto y la obtención de fondos (Ballestero 2013). La propuesta incluyó el diseño de una serie de maquetas a cargo del escultor alemán, quien trabajó sobre las colecciones de restos fósiles del Museo de La Plata.

En los años previos el mismo artista había tenido la oportunidad de revisar parte de las colecciones paleontológicas a cargo de Ameghino en el Museo Nacional. En una carta, agradeciendo la buena disposición del Director por facilitarle los materiales, escribió:

"Al mismo tiempo me permito mandar a Vd. unas fotografías de animales prehistóricos que he hecho de mis estudios de la República Argentina, y le sería muy obligado si $\mathrm{Vd}$. me escribiera cómo estos modelos le han gustado.

Si Vd. tendría la intención que le haga algo de estos en grande para su instituto, estoy a la disposición de Vd. Con precios y explicaciones" (Pallenberg [1911] 1936: 385).

Dos cuestiones sobresalen de este ejemplo para pensar la popularización de las ciencias, su espectacularización en grandes proyectos y la dinámica de la relación entre los científicos y los artistas. Por una parte, la importancia de contar con la revisión de Ameghino sobre los modelos que había realizado. Con el envío de las fotos esperaba conocer su opinión, muy valorada como experto en fósiles, y así poder certificar la calidad de su trabajo.

Las intenciones comerciales de Pallenberg eran bastante claras, buscando algún tipo de financiamiento, que sería más factible si se vehiculizaba por los caminos institucionales y de la relación con el personal de los museos. Estos, tal como sucedió con Lehmann-Nitsche podían mediar con las autoridades nacionales para obtener fondos.

El proyecto de construir un parque paleontológico también tomó visibilidad en la prensa ilustrada. En 1912 Lehmann-Nitsche escribió una nota al respecto para la revista Fray Mocho (Figura 8). Allí explicó someramente la importancia de desarrollar un parque temático y destacó el trabajo del artista. En efecto el grueso del texto y de las imágenes versó sobre las maquetas en yeso realizadas por él, agradeciendo el envío de las fotografías publicadas que daban "idea de la belleza de las esculturas" (LehamannNitche 1912).

El relato era claramente visual, ubicando las fotografías y la ilustración en el centro de la hoja para explicar dos posibles diseño para el parque. Siempre en su escala natural, las réplicas podían montarse sobre un zócalo "como cualquier estatua de un héroe fósil" (LehamannNitche 1912). La otra opción era reconstruir el paisaje natural, de modo de presentar las réplicas "... escondidas en el follaje o al margen de una laguna, etc., y parecen ser animales vivos" (Lehamann-Nitche 1912). La ilustración en el centro de la página iba en ese sentido y reforzaba la "idea del aspecto artístico y sorprendente que presenta la fauna gigantesca de antaño" (Lehamann-Nitche 1912).

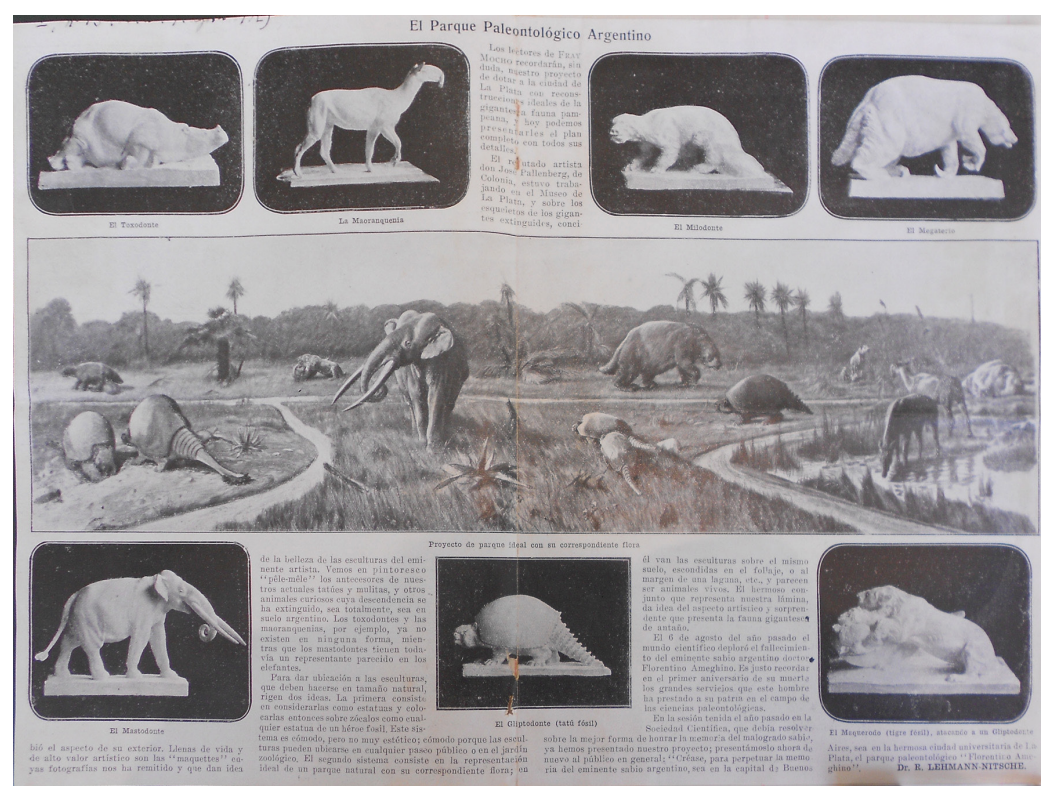

Figura 8. Proyecto de parque temático en la prensa ilustrada. Fotografías de las maquetas de diferentes mamíferos fósiles diseñadas por Jose Pallenberg. La ilustración central representaba cómo se hubiera visto el proyecto concretado. Publicado por Lehamann-Nitche, Robert "El parque paleontológico argentino", en Fray Mocho, 9 de agosto de 1912.

Figura 8. Theme park project in the illustrated press. Photographs of the models of different fossil mammals designed by Jose Pallenberg. The central illustration represented how the concrete project would have looked. Published by Lehamann-Nitche, Robert "The Argentine paleontological park", in Fray Mocho, August 9, 1912

ISSN 1852-060X (impreso) / ISSN 1852-4826 (electrónico) 
Destacamos el relato construido a través de las imágenes como un aspecto característico de esta publicación. Las figuras ocupaban un lugar central procurando que los lectores, como sucedía con los museos, pudieran imaginar la vida en el pasado.

\section{Conclusiones}

Con los ejemplos que presentamos buscamos indagar en los procesos de conformación de los saberes y las prácticas vinculadas con la construcción de un pasado remoto que posteriormente se catalogó como científico. Esa prehistoria como tiempo y saber fue, a la vez que un campo científico, un campo popular, visual y material. Presente en los medios gráficos, los textos escolares, las exhibiciones de museos y el diseño de parques temáticos, en cada caso condensó algún aspecto vinculado con las prácticas científicas, quiénes las realizaban, los materiales que utilizaban y los contenidos representados.

La hipótesis explicativa sobre el uso de las corazas de edentados fósiles como viviendas de los humanos prehistóricos tuvo su correlato visual, estético y popular, en el mural del Museo de La Plata y sus múltiples reproducciones. En cada oportunidad fue conteniendo y resignificando saberes, acompañada de las necesidades y posibilidades específicas de los contextos de producción y uso, como una fotografía en blanco y negro y sus relatos asociados para enseñar en las escuelas o describir una visita al museo. La prensa diaria y semanal vectorizó los saberes de la prehistoria a través del registro de las personas, los trabajos y los materiales, haciendo eco de los debates en torno al problema de la antigüedad del hombre en la región rioplatense. En todos los casos analizados se destaca el componente visual, como objeto que se mira o como acción que era posada, problematizada, discutida como evidencia o promovida en función de quienes eran sus productores y públicos consumidores.

Bahía Blanca, 21 de octubre de 2019

\section{Bibliografía}

Ameghino, F. (1879a) La plus haute antiquité de l'homme dans le Nouveaux-Monde. En Compte rendu de la troisième sesión Congrès international des Américanistes 2 : 198-306.

Ameghino, F. (1879b) L'Homme Préhistorique dans La Plata. Revue d'Anthropologie 2 (2): 208-249.

Ameghino, F. ([1880-1881] 1947) La antigüedad del hombre en el Plata. Intermundo: Buenos Aires.

Ameghino, F. ([1884] 1935) Filogenia: Principios de clasificación transformista basados sobre leyes naturales y proporciones matemáticas (pp. 215-559). En Obras
Completas y Correspondencia Científica de Florentino Ameghino 4. La Plata: Impresiones Oficiales.

Ameghino, F. (1908) Notas preliminares sobre el Tetraprothomo argentinus. Un precursor del hombre del mioceno superior de Monte Hermoso. Anales del Museo Nacional de Buenos Aires III(IX): 105-242.

Ballestero, D. (2013) Los espacios de la antropología en la obra de Robert Lehmann-Nitsche, 1894-1938. Tesis de Doctorado para obtener el título de Dr. en Ciencias Naturales, Facultad de Ciencias Naturales y Museo UNLP.

Ballestero, D. y Sardi, M. (2016) Enseñanza de la Antropología física en la Argentina de comienzos de siglo XX. Robert Lehmann-Nitsche y la formación de discípulos. Revista del Museo de Antropología 9(1): 107-120.

Bonomo, M. (2002) El Hombre Fósil de Miramar. Intersecciones en Antropología 3: 69-85.

Carden, F. (2005) Museo de La Plata. Los murales y su entorno. Revista Museo 19 (3): 25-30.

Carden, F. (2009) Los murales del Museo de La Plata. La Plata: Fundación Museo La Plata.

"Caricaturas contemporáneas" (17 de mayo de 1902). Caras y Caretas 5(189).

Castro, V. (1912) Memoria anual del Presidente de la Sociedad Científica Argentina correspondiente al XXXIX período administrativo ( $1^{\circ}$ abril de 1911 a 31 de marzo de 1912). Anales de la Sociedad Científica Argentina LXXIII: 292-304.

"El nuevo director del Museo Nacional" (26 de abril de 1902). Caras y Caretas 5(188).

Eskildsen, K. (2012) The Language of Objects. Christian Jürgensen Thomsen's Science of the Past. Isis 103: 24-53.

Farro, M. (2009) La formación del Museo de La Plata. Coleccionistas, comerciantes, estudiosos y naturalistas viajeros a fines del siglo XIX. Rosario: Prohistoria.

Farro, M. (2012) Imágenes de cráneos, retratos antropológicos y tipologías raciales. Los usos de las primeras colecciones fotográficas del Museo de La Plata a fines del siglo XIX. En Kelly, T. y Podgorny, I. (dir.) LoS secretos de barba azul. Fantasías y realidades de los archivos del Museo de La Plata. Rosario: Prohistoria.

Gamble, C. y Kruszynski, R. (2009) John Evans, Joseph Prestwich and the Stone that shattered the time barrier. Antiquity 83: 461-475.

Goodrum, M. (2009) The Creation of Societies for the 
Study of Prehistory and Their Role in the Formation of Prehistoric Archaeology as a Discipline, 1867-1929. Bulletin of the History of Archaeology 19: 27-35.

Goodrum, M. (2014) Crafting a New Science. Defining Paleoanthropology and Its Relationship to Prehistoric Archaeology, 1860-1890. Isis 105(4): 706-733.

Herrero Ducloux, E. (1 de enero de 1907) Institutos científicos argentinos. El museo de La Plata. En diario La Prensa.

Lehmann-Nitsche, R. (1907) Nouvelles recherches sur la formation pampéenne et l'homme fossile de la République Argentine, recueil de contributions scientifiques de $\mathrm{Mm}$. C. Burkhardt, A. Doering, J. Frueh, $H$. Von Ihering, $H$. Leboucq, R. Lehmann-Nitsche, E. Martin, S. Roth, W. B. Scott, G. Steinmann et F. Zirkel. Revista del Museo de La Plata XIV: 143-488.

Lehamann-Nitche, R. (9 de agosto 1912) El parque paleontológico argentino. En Fray Mocho.

Malosetti Costa, L. y Burucúa ,J. (2011) Pintura italiana en Buenos Aires en torno a 1910 (pp. 319-344). En Sartor, M. (coord.) América latina y la cultura artística italiana. Un balance en el Bicentenario de la Independencia Latinoamericana. Buenos Aires: Instituto Italiano de Cultura.

Moreno, F. (1890-1891) El Museo de La Plata. Rápida ojeada sobre su fundación y desarrollo. Revista del Museo de La Plata tomo I: 27-55.

Moser, S. (1992) The visual language of archaeology: A case study of the Neanderthals. Antiquity 66: 831-844.

Moser, S. (1998) Ancestral Images: The Iconography of Human Origins. Ithaca: Cornell University Press.

Moser, S. y Smiles, S. (2005) Introduction: The Image in Question (pp. 1-13). En Envisioning the Past. Archaeology and the Image. Londres: Blackwell Publishing.

"Notas científicas. El hombre fósil" (25 de diciembre de 1912). En La Nación.

"Notas Científicas. Homo Sinemento" (3 de agosto de 1913). En La Nación.

O'Connor, A. (2007) Finding Time for the Old Stone Age. A History of Palaeolithic Archaeology and Quaternary Geology in Britain, 1860-1960. Oxford: University Press.

Outes, F. y Bruch, C. (1910) Los aborígenes de la República Argentina. Manual adaptado a los programas de las Escuelas Primarias, Colegios Nacionales y Escuelas
Normales. Buenos Aires: Angel Estrada y cía.

Pallenberg, J. "Carta a Florentino Ameghino, Buenos Aires, 24/6/1911" (p. 385). En Torcelli, A. (dir.) OC. y CC 23. La Plata: Taller de impresiones oficiales.

Podgorny, I. (1997) De la santidad laica del científico Florentino Ameghino y el espectáculo de la ciencia en la Argentina moderna. Entrepasados 13: 37-61.

Podgorny, I. (2009) El sendero del tiempo y de las causas accidentales. Los espacios de la prehistoria en la Argentina, 1850-1910. Rosario: Prohistoria.

Podgorny, I. (2015) Human Origins in the New World? Florentino Ameghino and the Emergence of Prehistoric Archaeology in the Americas (1875-1912). PaleoAmerica 1 (1): $68-80$.

Podgorny, I. (2016) The Daily Press Fashions a Heroic Intellectual: The Making of Florentino Ameghino in Late Nineteenth-Century Argentina. Centaurus 58: 166-184.

Rudwick, M. (1992) Scenes from the Deep Time. Early pictorial representations of the prehistorical world. Chicago: The Chicago University Press.

Rudwick, M. (2000) Georges Cuvier's paper museum of fossil bones. Archives of Natural History 1(27): 51-68.

Ruiz Zapatero, G. (1997) Héroes de piedra en papel: La prehistoria en el cómic. Complutum 8: 285-310.

Simón, C. (2018a) Los dispositivos visuales y la constitución de las evidencias en la arqueología argentina, 1850-1920. Tesis para obtener el título de Doctor de la Universidad de Buenos Aires en Arqueología. Disponible en FILODIGITAL. URI: http://repositorio.filo. uba.ar/handle/filodigital/10770.

Simón, C. (2018b) Debates científicos y visuales: una aproximación a los procesos de producción de imágenes en las ciencias de la prehistoria rioplatense (1860-1890). Caiana13: 17-32.

URL:http://caiana.caia.org.ar/template/caiana. php?pag=articles/article_2.php\&obj=321\&vol=13.

Szir, S. (2009) Entre el arte y la cultura masiva. Las ilustraciones de la ficción literaria en Caras y Caretas (1989-1908) (pp. 109-140). En Malosetti Costa, L. y Gené, M. (comp.) Impresiones porteñas. Imagen y palabra en la historia cultural de Buenos Aires. Buenos Aires: Edhasa.

Szir, S. (2011) El semanario popular ilustrado Caras y Caretas y las transformaciones del paisaje cultural de la modernidad Buenos Aires 1898-1908. Tesis para obtener el título de Doctor de la Universidad de Buenos Aires en Letras. Consultada en FILODIGITAL. URI: http:// 
repositorio.filo.uba.ar/handle/filodigital/1886.

Szir, S. (2013) Reporte documental, régimen visual y fotoperiodismo. La ilustración de noticias en la prensa periódica en Buenos Aires (1850-1910). Caiana 3. Disponible en: http://caiana.caia.org.ar/template/caiana. php?pag=articles/article_2.php\&obj=121\&vol=3.

Sommer, M. (2006) Mirror, Mirror on the wall: Neanderthal as Imagen and 'Distortion' in Early 20th-Century French
Science and Press. Social Studies of Science 36(2): 207240.

Tell, V. (2009) Reproducción fotográfica e impresión fotomecánica: materialidad y apropiación de imágenes a fines del siglo XIX (pp.141-164). En Malosetti Costa, L. y Gené, M. (comp.) Impresiones porteñas. Imagen y palabra en la historia cultural de Buenos Aires. Buenos Aires: Edhasa. 